\title{
Chemical Analysis of Essential Oils from Ocotea gomezii W.C. Burger and Ocotea morae Gómez-Laur. (Lauraceae) Collected at "Reserva Biológica Alberto M. Brenes" in Costa Rica and their Cytotoxic Activity on Tumor Cell Lines
}

\author{
Carlos Chaverri, ${ }^{a}$ Cecilia Díaz $z^{b}$ and José F. Ciccio ${ }^{*, a}$ \\ ${ }^{a}$ Centro de Investigaciones en Productos Naturales (CIPRONA) and Escuela de Química and \\ ${ }^{b}$ Instituto Clodomiro Picado, Facultad de Microbiología and Departamento de Bioquímica, Escuela de \\ Medicina, Universidad de Costa Rica, San José, Montes de Oca, San Pedro, 11501-2060 Costa Rica
}

\begin{abstract}
A composição química dos óleos essenciais obtidos de folhas, cascas e troncos de Ocotea gomezii e $O$. morae de populações silvestres da Costa Rica, está sendo descrita pela primeira vez. Os óleos de $O$. gomezii são constituídos principalmente por sesquiterpenóides enquanto os de $O$. morae apresentaram mono- e sesquiterpenóides na mesma proporção. A análise da composição química por CG/EM e CG/DIC resultou na identificação de 166 componentes, correspondente a 89,4-98,1\% dos óleos totais. Quando comparada a atividade de todos os óleos obtidos sobre linhagens de células CCF-STTG1, Hep3B, HepG2, H-460, AGS, N-87, SW-620, MCF-7 e VERO, observou-se que as células de astrocitoma foram as mais resistentes aos mesmos. Concluiu-se que os óleos essenciais de folhas, cascas e tronco de Ocotea gomezii e Ocotea morae podem conter alguns compostos tóxicos, mas o uso potencial dos mesmos contra as células tumorais foi muito baixo, pois são tóxicos na mesma extensão, para as linhagens de células tumorais e não-tumorais.
\end{abstract}

The chemical composition of the essential oils of the leaves, bark and wood of Ocotea gomezii and $O$. morae from Costa Rica, were analyzed by capillary GC-FID and GC-MS. The oils of $O$. gomezii were predominantly composed by sesquiterpenoids whereas the oils of $O$. morae had both monoterpenoids and sesquiterpenoids. Analysis by GC/MS and GC/FID resulted in the identification of 166 compounds, representing about $89.4-98.1 \%$ of the total oils. When we compared the effect of the oils on cell lines (CCF-STTG1, Hep3B, HepG2, H-460, AGS, N-87, SW-620 and MCF-7 and VERO), we found that astrocytoma cells were the most resistant ones. We conclude that the essential oils of Ocotea gomezii and Ocotea morae could have some toxic compounds, but the potential use of them against the tumor cells would be very low, since they could be toxic to tumor and non-tumor cells in the same extent.

Keywords: Ocotea gomezii, O. morae, Lauraceae, essential oils, cytotoxicity

\section{Introduction}

The genus Ocotea (Lauraceae) is widely represented in the American Tropics with 300-400 species, being the largest genus of this family in Mesoamerica, with 102 species. ${ }^{1}$ Lauraceae is a family with about 2500 3000 species of mostly tropical trees. ${ }^{2}$ This family is an important component of cloud forests in Costa Rica where the individuals occur in high abundance and diversity., It can be recognized by the simple, alternate, stiff and aromatic elliptic to obovate leaves and fruits often borne in a cup. Worldwide, this family has a considerable economic

*e-mail: jfciccio@gmail.com importance because it is used as a source of timber for construction and furniture (Nectandra, Ocotea, Persea spp.), as a crop (Persea americana Mill., avocado), and to obtain flavors for food industry, perfumery and medicines (Cinnamomum zeylanicum B1., C. cassia Pressl.).

Ocotea gomezii W.C. Burger is an unusual species distinguished by its ferruginous puberulence and broadly rounded leaves. It is a tree of about 6-10 $\mathrm{m}$ tall and endemic of Costa Rica. The geographic distribution of the species includes the Central Volcanic Mountain and extends from near Volcán Rincón de la Vieja in the West, to Moravia de Chirripó in the East of Costa Rica. ${ }^{3}$ O. morae Gómez-Laur. is a tree of $18-22 \mathrm{~m}$ tall, with large fruits, readily recognized by their large $65 \mathrm{~mm}$ broad cupules, and $58 \mathrm{~mm}$ long and 
60 mm wide fruits. ${ }^{5}$ This tree is also endemic of Costa Rica and its geographic distribution is restricted to the humid Cordillera de Tilarán slopes at $c a .850 \mathrm{~m}$ of elevation at the "Reserva Biológica Alberto M. Brenes", managed and administered by the Universidad de Costa Rica. ${ }^{6}$

Several phytochemical investigations have been performed on plants of the genus Ocotea. These plants are well known as a source of aporphine alkaloids, ${ }^{7,8}$ lignans and neolignans ${ }^{9,10}$ and phenylpropanoids. ${ }^{11}$ The chemical composition of the volatile oils of Ocotea species has been the subject of several studies. ${ }^{12-37}$

These two endemic plants, Ocotea gomezii and $O$. morae, are barely studied from the chemical point of view. One report indicates that the aporphine alkaloid (+)-preocoteine is present in the bark of O. gomezii. ${ }^{38}$

Several Ocotea essential oils have been studied for their biological activities. For instance, oils from flower calyces and leaves of $O$. quixos ("flor de canela", American cinnamon) presented in vitro antioxidant, antibacterial and antifungal activities ${ }^{24,39}$ and also anti-inflammatory ${ }^{40}$ and antiplatelet properties. ${ }^{41,42}$ Oil from the calyces of $O$. bofo also presented antimicrobial and antioxidant activities. ${ }^{28}$ Essential oil from the stem bark of $O$. bracteosa presented molluscicidal activity, ${ }^{33}$ and oils of $O$. duckei showed significant cardiovascular effects. ${ }^{37}$ Setzer and co-workers ${ }^{29}$ also determined the activity of leaf essential oils of ten Ocotea species from Monteverde, Costa Rica, against cruzain (Chagas disease).

Regarding the cytotoxic effect against human cells, there are several studies with Ocotea species that include: O. endresiana, ${ }^{36}$ O. floribunda, ${ }^{35}$ O. meziana, ${ }^{43} O$. praetermissa, ${ }^{36}$ O. tonduzii, ${ }^{34}$ O. veraguensis,${ }^{44}$ O. white $i^{44}$ and some unidentified ones (Ocotea new species "los llanos" and Ocotea new species "small leaf"). ${ }^{43}$ Basically, it has been demonstrated that some of them showed some toxicity against breast cancer cells. ${ }^{34,36,43,44}$ There is also one study with essential oil from $O$. floribunda that showed cytotoxicity against hepatoma cells HepG2. ${ }^{35}$

In this paper, we report the chemical composition and cytotoxic properties of six essential oils obtained from $O$. gomezii and $O$. morae from three different parts of the plants (leaves, bark and wood) and we show their complex composition and inespecific toxicities.

\section{Experimental}

\section{Plant collection and oil isolation}

Plant materials were collected in May, 2000 at the "Reserva Biológica Alberto M. Brenes" near the San Lorencito River, in the humid Caribbean slope of the Tilarán mountain range, province of Alajuela. Voucher specimens were deposited at the Herbarium of the Universidad de Costa Rica (herbarium numbers USJ-30631, USJ-77417). The samples were dried in the shade at room temperature (4 days). Then, the plant material was chopped and submitted to hydrodistillation $(3 \mathrm{~h})$ by using a modified Clevengertype apparatus. The distilled oils were collected and dried over anhydrous sodium sulfate (Merck) and stored in a refrigerator. The yields $(\mathrm{v} / \mathrm{m})$ of the oils were: $O$. gomezii (leaves $0.4 \%$, bark $0.1 \%$, and wood $0.1 \%$ ); O. morae (leaves $0.5 \%$, bark $0.3 \%$, and wood $0.2 \%$ ). The oils were labeled as, $O g \mathrm{~L}$ : Ocotea gomezii (leaves), $O g \mathrm{~B}:$ O. gomezii (bark), OgW: O. gomezii (wood), OmL: Ocotea morae (leaves), OmB: O. morae (bark) and OmW: O. morae (wood).

\section{Chemical analysis}

The oils of $O$. gomezii and $O$. morae were analyzed by GC-FID using a Shimadzu GC-17 gas chromatograph with a Shimadzu Class-VP, version 4.3 software. The GC column was a Heliflex AT-5 (Alltech), 5\% phenyl-95\% methylpolysiloxane fused silica capillary $(30 \mathrm{~m} \times 0.25 \mathrm{~mm}$; film thickness $0.20 \mu \mathrm{m})$. Operating conditions were: carrier

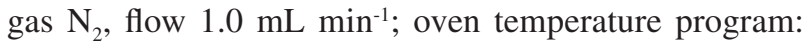
$60-220{ }^{\circ} \mathrm{C}$ at $3{ }^{\circ} \mathrm{C} \mathrm{min}^{-1}, 220{ }^{\circ} \mathrm{C}$ (10 min); injection size: $0.1 \mu \mathrm{L}$ (pure oil); sample injection port temperature $250^{\circ} \mathrm{C}$; detector temperature $275^{\circ} \mathrm{C}$; split 1:50.

The analysis by GC-MS was performed using a Shimadzu GC-17A gas chromatograph coupled with GCMS-QP5050 apparatus and CLASS 5000 software with Wiley 138 computer database. The GC column was a Heliflex AT-5 (Alltech), 5\% phenyl- 95\% methylpolysiloxane fused silica capillary $(30 \mathrm{~m} \times 0.25 \mathrm{~mm}$; film thickness $0.20 \mu \mathrm{m})$. Operating conditions were: carrier

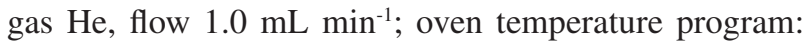
60-240 ${ }^{\circ} \mathrm{C}$ at $3{ }^{\circ} \mathrm{C} \mathrm{min}^{-1}$; injection size: $0.1 \mu \mathrm{L}$ (pure oil); sample injection port temperature $250{ }^{\circ} \mathrm{C}$; detector temperature $260{ }^{\circ} \mathrm{C}$; ionization voltage: $70 \mathrm{eV}$; ionization current $60 \mu \mathrm{A}$; scanning speed $0.5 \mathrm{~s}$ over $38-400 \mathrm{amu}$ range; split 1:70.

Identification of the oil components was performed using the retention indices on a DB- 5 type column, ${ }^{45}$ and by comparison of their mass spectra with either those published in the literature ${ }^{46}$ or those from our own database. Integration of the total chromatogram, expressed as area percent, has been used to obtain quantitative compositional data.

\section{Cell culture}

Astrocytoma (CCF-STTG1), hepatocellular carcinoma (Hep3B, HepG2), lung large cell carcinoma (H-460), 
gastric carcinoma (AGS, N-87), colon adenocarcinoma (SW-620), breast carcinoma (MCF-7) and kidney epithelial (Vero) cell lines were obtained from the American Type Culture Collection (ATCC) or National Cancer Institute (NCI), USA. Cells were maintained in Dulbecco essential medium supplemented with $10 \%$ fetal bovine serum, $2 \mathrm{mmol} \mathrm{L}^{-1}$ of glutamine, $100 \mathrm{IU} \mathrm{mL}^{-1}$ of penicillin and amphotericin B in a $37{ }^{\circ} \mathrm{C}$ humidified incubator under an atmosphere of $7 \% \mathrm{CO}_{2}$ on air. For the experiments, cells were cultured in 96-well plates $(15,000$ cells/well) and allowed to adhere overnight.

\section{Cytotoxicity assay}

Various concentrations of essential oils, previously dissolved in $95 \%$ ethanol, were added to the plates in $100 \mu \mathrm{L}$ of fresh medium and incubated for $48 \mathrm{~h}$. After incubation, [3-(4,5-dimethylthiazol-2-yl)-2,5diphenyltetrazolium bromide] (MTT) was added to each well to a final concentration $0.5 \mathrm{mg} \mathrm{mL}^{-1}$ and after $2 \mathrm{~h}$ at $37^{\circ} \mathrm{C}$ medium was carefully removed from the plates and $95 \%$ ethanol was added to the wells with the purpose of dissolving formazan crystals. ${ }^{47}$ Absorbances were read at $570 \mathrm{~nm}$ and viability percentages were calculated, using samples incubated with $95 \%$ ethanol dissolved in culture medium as $100 \%$ viability values. $(R)-(+)$ Limonene (Sigma Aldrich) was used as a standard to assure its values were always constant and the cells remained equally resistant to its effects in every performed experiment. $\mathrm{LD}_{50}$ values were calculated from concentration versus viability plots using SlideWrite ${ }^{\circledR}$ Plus 6.1 (Advanced Graphics Software, Inc., Carlsbad, CA), to obtain the concentrations able to induce $50 \%$ of cytotoxicity.

\section{Statistical analysis}

Cytotoxicity values were analyzed by ANOVA followed by Tukey's test and $\mathrm{p}<0.05$ were considered statistically significant.

\section{Results and Discussion}

From the hydrodistilled oils, a total of 166 compounds were identified, accounting for $89.4-98.1 \%$ of the total composition of the essential oils. The chemical composition of the volatiles is listed in Table S1 (see Supplementary Information, SI).

Essential oils from $O$. gomezii were rich in sesquiterpenoids (67.3-94.9\%) with a minor quantity of monoterpenoids $(0.7-12.6 \%)$. Main constituents of the leaf oil were pentan-2-ol (12.5\%), epi- $\alpha$-cadinol (9.8\%), $\delta$-cadinene $(7.7 \%)$ and 1,8-cineole $(6.0 \%)$ along with small amounts of $\gamma$-cadinene, cis-muurola-4(14),5-diene, $\alpha$-muurolene and oxygenated sesquiterpenes viridiflorol, 1,10-di-epi-cubenol and globulol. O. gomezii bark essential oil was composed primarily of sesquiterpenoids $(94.9 \%)$ and contained $\delta$-cadinene $(14.5 \%), 1,10$-diepi-cubenol (7.7\%), and $\alpha$-muurolene (6.9\%) along with small amounts of $\gamma$-cadinene, allo-aromadendrene, $\alpha$-cubebene, $\alpha$-cadinol, epi- $\alpha$-cadinol, globulol and viridiflorol. Main compounds of wood oil of $O$. gomezii

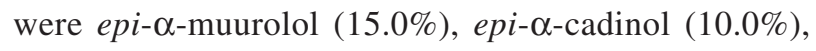
and $\delta$-cadinene $(7.7 \%)$, along with small amounts of 1,10-di-epi-cubenol, khusinol, epizonarene, viridiflorol and globulol. Moreover, essential oils from $O$. gomezii were rich in sesquiterpenes of the cadinene type (ca. 47$65 \%$ ) mainly based on the cadinane and the muurolane skeletons.

Essential oils from the other analyzed species, $O$. morae, were all rich in sesquiterpenoids (54.0-71.0\%) and monoterpenoids (24.3-42.5\%). Leaf oil was composed by monoterpenoids $\beta$-pinene (17.5\%), $\alpha$-pinene (10.4\%) and 1,8 -cineole (7.3\%), and sesquiterpenes bicyclogermacrene $(8.8 \%)$, germacrene $\mathrm{D}(7.5 \%), \beta$-caryophyllene $(7.1 \%)$ and $\beta$-selinene. Major constituents of bark oil were 1,8-cineole $(12.8 \%)$ and $\beta$-caryophyllene (6.1\%), along with small amounts of $\delta$-cadinene, caryophyllene oxide, $\beta$-selinene, $\alpha$-cadinol, 1-epi-cubenol and spathulenol. Sesquiterpenoids $(71.0 \%)$ were the main constituents of wood essential oil of O. morae, containing $(E)$-nerolidol as the main constituent $(11.4 \%)$ accompanied by other sesquiterpenoids such as epi- $\alpha$-muurolol (6.3\%), $\delta$-cadinene $(6.2 \%), \alpha$-cadinol (6.0\%), $\beta$-caryophyllene, $\beta$-cubebene and $\alpha$-copaene. Also, there were present the monoterpenoids 1,8-cineole (7.1\%), camphene and $\alpha$-pinene.

The oils were predominantly terpenoid in nature like other studied Ocotea oils from Costa Rica. ${ }^{26,30,32}$ Of the six oils analyzed in this work only the leaf oil from $O$. morae contained a very small quantity of the benzenoid compounds benzaldehyde $(0.1 \%)$ and the esters benzyl benzoate $(0.4 \%)$ and benzyl salicylate $(0.1 \%)$. Oils from Costa Rica Ocotea spp. are lacking of phenylpropanoid constituents (like safrole, cinnamaldehyde, methylcinnamate, $O$-methyleugenol, asaricin, elemicin, and others, all volatiles with distinctive aromas) that are typical of some Ocotea essential oils mainly from South America origin. ${ }^{12-25}$

We determined the cytotoxicity of essential oils on eight different tumor cell lines, and non-tumoral cells (Vero). Cell lines were derived from tumors from lung, liver, colon, breast, stomach (primary tumor and liver metastasis) and an astrocytoma (Table 1). Except for bark 
Table 1. $\mathrm{LD}_{50}$ of six essential oils obtained from different parts of the plants $O$. gomezii and O. morae

\begin{tabular}{|c|c|c|c|c|c|c|c|}
\hline Cell line & $\begin{array}{c}O g \mathrm{~L} \\
\left(\mu \mathrm{g} \mathrm{mL}{ }^{-1}\right)\end{array}$ & $\begin{array}{c}O g \mathrm{~B} \\
\left(\mu \mathrm{g} \mathrm{mL} \mathrm{mL}^{-1}\right)\end{array}$ & $\begin{array}{c}O g \mathrm{~W} \\
\left(\mu \mathrm{g} \mathrm{mL} \mathrm{mL}^{-1}\right)\end{array}$ & $\begin{array}{c}O m L \\
\left(\mu \mathrm{g} \mathrm{mL} \mathrm{L}^{-1}\right)\end{array}$ & $\begin{array}{c}O m \mathrm{~B} \\
\left(\mu \mathrm{g} \mathrm{mL} \mathrm{m}^{-1}\right)\end{array}$ & $\begin{array}{c}O m W \\
\left(\mu \mathrm{g} \mathrm{mL}^{-1}\right)\end{array}$ & $\begin{array}{l}\text { Limonene } \\
\left(\mu \mathrm{g} \mathrm{mL}^{-1}\right)\end{array}$ \\
\hline Vero (non-tumoral) & $175 \pm 21$ & $150 \pm 28$ & $456 \pm 83^{a}$ & $344 \pm 44$ & $293 \pm 47$ & $234 \pm 52$ & $896 \pm 152$ \\
\hline H460 (lung) & $160 \pm 30$ & $119 \pm 9$ & $414 \pm 41^{b}$ & $353 \pm 105$ & $139 \pm 31$ & $218 \pm 52^{\mathrm{a}}$ & $616 \pm 74$ \\
\hline HepG2 (liver) & $137 \pm 48$ & $79 \pm 20$ & $94 \pm 4^{\mathrm{c}}$ & $187 \pm 55^{a}$ & $178 \pm 50$ & $166 \pm 41^{b}$ & $1032 \pm 45$ \\
\hline Hep3B (liver) & $137 \pm 21$ & $124 \pm 33$ & $293 \pm 16^{\mathrm{d}}$ & $282 \pm 110^{b}$ & $201 \pm 22$ & $278 \pm 23$ & $466 \pm 85$ \\
\hline SW620 (colon) & $122 \pm 15$ & $94 \pm 10$ & $187 \pm 20^{\mathrm{e}}$ & $201 \pm 27^{c}$ & $132 \pm 50$ & $190 \pm 30$ & $924 \pm 76$ \\
\hline MCF7 (breast) & $167 \pm 22$ & $160 \pm 1$ & $181 \pm 79^{\mathrm{f}}$ & $274 \pm 19^{d}$ & $186 \pm 18$ & $260 \pm 11$ & $629 \pm 211$ \\
\hline AGS (stomach) & $109 \pm 27^{a}$ & $95 \pm 7$ & $260 \pm 11^{g}$ & $183 \pm 55^{\mathrm{e}}$ & $185 \pm 10$ & $209 \pm 36$ & $774 \pm 53$ \\
\hline N87 (stomach, metastasis) & $239 \pm 52$ & $132 \pm 11$ & $418 \pm 117^{\mathrm{h}}$ & $403 \pm 46$ & $234 \pm 19$ & $256 \pm 15$ & $796 \pm 205$ \\
\hline CCF-STTG1 (astrocytoma) & $297 \pm 12^{a}$ & $184 \pm 38$ & $862 \pm 144^{\mathrm{a}, \mathrm{b}, \mathrm{c}, \mathrm{d}, \mathrm{e}, \mathrm{f}, \mathrm{g} \mathrm{h}}$ & $744 \pm 2^{\text {a,b.c,d,e }}$ & $262 \pm 67$ & $587 \pm 221^{\mathrm{a}, \mathrm{b}}$ & $833 \pm 24$ \\
\hline
\end{tabular}

*Superscript letters represent statistically significant differences in the cytotoxicity observed between some of the oils on the different cell lines (comparison is made in each column). $\mathrm{p}<0.05$ is considered statistically significant. Limonene is used as an internal standard. OgL: Ocotea gomezii (leaves); $O g$ B: $O$. gomezii (bark); OgW: O. gomezii (wood); OmL: O. morae (leaves); OmB: O. morae (bark); OmW: O. morae (wood).

oils, all the other volatiles showed statistically significant differences in toxicity between astrocytoma cells and the other ones, but the effect was not observed among the other cell lines, or between tumor cell lines and non-tumor Vero cells. When we compared the effect of the oils taking all the cell lines together, we only observed statistically significant differences between samples $O g \mathrm{~B}$ and $O g \mathrm{~W} ; O g \mathrm{~B}$ and $O m \mathrm{~L}$ and $O g \mathrm{~W}$ and $O g \mathrm{~L}$. The effect of limonene was very low compared to the volatiles tested, but worked well as an internal standard for the experiments, to assure the cells were kept under the same degree of sensitivity along the time they were in culture.

One of the few Ocotea essential oils reported in the literature for its biological activities is $O$. quixos, which shows antifungical and antibacterial activities. ${ }^{39}$ This leaf oil presents as main identified compounds: caryophyllene, humulene and eremophyllene. The first compound is present in significant amounts in O. morae oils too, whereas humulene is present in small amounts in the oils of both plants analyzed here.

There are just a few reports in the literature regarding the toxic effect of Ocotea essential oils on animal cells, and most of the studies have been carried out in breast cancer cells only. ${ }^{34-36,43,44}$ We showed here that these species have some toxicity, but due to their complex chemical composition, no assumptions can be made about the compounds responsible for these activities. Compounds such as germacrene $\mathrm{D}, \beta$-caryophyllene, $\alpha$-cadinene and $\alpha$ - and $\beta$-pinene have been shown to be toxic on cell lines such as MCF-7, a breast carcinoma cell line. ${ }^{43}$ All these compounds are present in the Ocotea species tested in this article, so they could be responsible for the relative toxicity observed here. Another compound found in these volatiles, 1,8-cineole, has been shown to induce apoptosis on KB cells (human oral epidermoid carcinoma), indicating that could play a role in the cytotoxicity observed here. ${ }^{48}$ Some antagonistic effects between some of the compounds present in these oils have been also reported in the literature. ${ }^{43}$

\section{Supplemantary Information}

Supplementary data (Table S1) are available free of charge at http://jbcs.sbq.org.br, as PDF file.

\section{Acknowledgments}

The authors are grateful to Vicerrectoría de Investigación (UCR) (Project 809-A4-006) for partial financial support, to V. Mora (Reserva Biológica Alberto M. Brenes) for the assistance with the plant collection, J. Gómez-Laurito (Escuela de Biología, UCR) for botanical identification of the species and L. Hernandez (CIPRONA) for technical assistance. Partial funding was also obtained from Project No. 809-A8-518.

\section{References}

1. van der Werff, H.; Ann. Missouri Bot. Gard. 2002, 89, 429.

2. Chanderbali, A. S.; van der Werff, H.; Renner, S. S.; Ann. Missouri Bot. Gard. 2001, 88, 104.

3. Burger, W. C.; van der Werff, H.; Fieldiana Bot. 1990, 23, 1.

4. Haber, W. A.; Zuchowski, W.; Bello, E.; AnIintroduction to Cloud Forest Trees: Monteverde, Costa Rica; Impresión Comercial La Nación S.A.: San José, Costa Rica, 1996, p. 134.

5. Gómez-Laurito, J.; Novon 1997, 7, 145. 
6. Salazar-Rodríguez, A. H.; InterSedes: Revista de las Sedes Regionales [online] 2004, 5 No. 009; http://redalyc.uaemex. $\mathrm{mx} / \mathrm{redalyc/src/inicio/ArtPdfRed.jsp?iCve=66650902}$

7. Castro, O. C. In Phytochemical Potential of Tropical Plants; Downum, K. R.; Romeo, J.; Stafford, H., eds.; Plenum Press: New York, 1993, ch. 3.

8. Zanin, S. M. W.; Lordello, A. L. L.; Quim. Nova 2007, 30, 92.

9. Ishige, M.; Motidome, M.; Yoshida, M.; Gottlieb, O. R.; Phytochemistry 1991, 30, 4121.

10. Lordello, A. L. L.; Yoshida, M.; Phytochemistry 1997, 46, 741.

11. Andrei, C. C.; Braz-Filho, R.; Gottlieb, O. R.; Phytochemistry 1988, 27, 3992 .

12. Mors, W. B.; Magalhães, M.T.; Gottlieb, O. R.; Perfum. Essent. Oil Record 1959, 50, 26.

13. Gottlieb, O. R.; Magalhães, M. T.; Perfum. Essent. Oil Record 1960, $51,18$.

14. Brooks, C. J. W.; Campbell, M. M.; Phytochemistry 1969, 8, 215.

15. Gottlieb, O. R.; Koketsu, M.; Magalhães, M. T.; Maia, J. G. S.; Mendes, P. H.; Da Rocha, A. I.; Da Silva, M. L.; Wilberg, V. C.; Acta Amazonica 1981, 11, 143.

16. Díaz, A. M. P. de; Díaz, P. P.; Joseph-Nathan, P.; Rev. Latinoamer. Quim. 1991, 22, 60.

17. Terreaux, C.; Maillard, M.; Hostettmann, K.; Lodi, G.; Hakizamungu, E.; Phytochem. Anal. 1994, 5, 233.

18. Weyerstahl, P.; Wahlburg, H-C.; Splittgerber, U.; Marshall, H.; Flavour Fragr. J. 1994, 9, 179.

19. Reynolds, T.; Kite, G.; J. Essent. Oil Res. 1995, 7, 415.

20. Zoghbi, M. das G. B.; Andrade, E. H. A. de; Santos, A. S.; Silva M. H. L. da; Maia, J. G. S. In LISBOA, P. L. B. (Org.), Caxiuanã, Belém: Museu Paraense Emilio Goeldi. (http://www. museu-goeldi.br/semicax/CBO_014.pdf), 1997.

21. Scora, R. W.; Scora, P. E.; J. Essent. Oil Res. 2001, 13, 37.

22. Lorenzo, D.; Loayza, I.; Leigue, L.; Frizzo, C.; Dellacassa, E.; Moyna, P.; Nat. Prod. Lett. 2001, 15, 163.

23. Menut, C.; Bessiere, J. M.; Hassani, M. S.; Buchbauer, G.; Schopper, B.; Flavour Fragr. J. 2002, 17, 459.

24. Bruni,R.;Medici,A.;Andreotti,E.;Fantin,C.;Muzzoli,M.;Dehesa, M.; Romagnoli, C.; Sacchetti, G.; Food Chem. 2004, 85, 415.

25. Pino, J. A.; Fernandes, P.; Marbot, R.; Sá-Fontinha, S.; J. Essent. Oil Res. 2004, 16, 131.

26. Chaverri, C.; Cicció, J. F.; Rev. Biol. Trop. 2005, 53, 431.

27. Sacchetti, G.; Guerrini, A.; Noriega, P.; Bianchi, A.; Bruni, R.; Flavour Fragr. J. 2006, 21, 674.

28. Guerrini, A.; Sacchetti, G.; Muzzoli, M.; Moreno Rueda, G.; Medici, A.; Besco, E.; Bruni, R.; J. Agric. Food Chem. 2006, 54,7778 .
29. Setzer, W. N.; Takaku, S.; Stokes, S. L.; Penton, A. F.; Pharmacologyonline 2006, 3, 785.

30. Chaverri, C.; Cicció, J. F.; J. Essent. Oil Res. 2007, 19, 439.

31. Fournet, A.; Ferreira, M. E.; Rojas de Arias, A.; Guy, I.; Guinaudeau, H.; Heinzen, H.; Fitoterapia 2007, 78, 382.

32. Takaku, S.; Haber, W. A.; Setzer, W. N.; Biochem. Syst. Ecol. 2007, 35, 525.

33. Coutinho, D. F.; Dias, C. S.; Barbosa-Filho, J. M.; Agra, M. F.; Martins, R. M.; Silva, T. M. S.; da-Cunha, E. V. L.; Silva, M. S.; J. Essent. Oil Res. 2007, 19, 482.

34. Bansal, A.; Moriarity, D. M.; Takaku, S.; Setzer, W. N.; Nat. Prod. Commun. 2007, 2, 781.

35. Werka, J. S.; Boehme, A. K.; Setzer, W. N.; Nat. Prod. Commun. 2007, 2, 1215.

36. Agius, B. R.; Setzer, M. C.; Stokes, S. L.; Walker, T. M.; Haber, W. A.; Setzer, W. N.; Int. J. Essent. Oil Ther. 2007, 1, 167.

37. Barbosa-Filho, J. M.; Cunha, R. M.; Dias, C. S.; Athayde-Filho, P. F.; Silva, M. S.; Leitao da-Cunha, E. V.; Machado, M. I. L.; Craveiro, A. A.; Medeiros, I. A.; Rev. Bras. Farmacogn. 2008, $18,37$.

38. López, J. A.; Barillas, W.; Gómez-Laurito, J.; Lin, F. T.; AlRehaily, A. J.; Sharaf, M. H.; Schiff, P. L. Jr.; Planta Med. 1995, $61,589$.

39. Noriega, P.; Dacarro, C.; La Granja 2008, 7, 3.

40. Ballabeni, V.; Tognolini, M.; Giorio, C.; Bertoni, S.; Bruni, R.; Barocelli, E.; Fitoterapia 2010, 8, 289.

41. Tognolini, M.; Barocelli, E.; Ballabeni, V.; Bruni, R.; Bianchi, A.; Chiavarini, M.; Impicciatore, M.; Life Sci. 2006, 78, 1419.

42. Ballabeni, V.; Tognolini, M.; Bertoni, S.; Bruni, R.; Guerrini, A.; Moreno-Rueda, G.; Barocelli, E.; Pharmacol. Res. 2007, $55,23$.

43. Wright, B. S.; Bansal, A.; Moriarity, D. M.; Takaku, S.; Setzer, W. N.; Nat. Prod. Commun. 2007, 2, 1241.

44. Moriarity, D. M.; Bansal, A.; Cole, R. A.; Takaku, S.; Haber, W. A.; Setzer, W. N.; Nat. Prod. Commun. 2007, 2, 1263.

45. van den Dool, H.; Kratz, P. D.; J. Chromatogr. 1963, 11, 463.

46. Adams, R. P.; Identification of Essential Oil Components by Gas Chromatography/ Quadrupole Mass Spectroscopy, $4^{\text {th }}$ ed.; Allured Publ. Corp.: Carol Stream, IL, 2007.

47. Denizot, F.; Lang, R.; J. Immunol. Methods 1986, 89, 271.

48. Cha, J.-D.; Kim, Y.-H.; Kim, J.-Y.; Food Sci. Biotechnol. 2010, 19, 185.

Submitted: August 10, 2010

Published online: January 20, 2011 


\section{Chemical Analysis of Essential Oils from Ocotea gomezii W.C. Burger and Ocotea morae Gómez-Laur. (Lauraceae) Collected at "Reserva Biológica Alberto M. Brenes" in Costa Rica and their Cytotoxic Activity on Tumor Cell Lines}

\section{Carlos Chaverri, ${ }^{a}$ Cecilia Díaz ${ }^{b}$ and José F. Ciccióo ${ }^{* a}$}

${ }^{a}$ Centro de Investigaciones en Productos Naturales (CIPRONA) and Escuela de Química and

${ }^{b}$ Instituto Clodomiro Picado, Facultad de Microbiología and Departamento de Bioquímica, Escuela de Medicina, Universidad de Costa Rica, San José, Montes de Oca, San Pedro, 11501-2060 Costa Rica

Table S1. Percentage composition of the essential oils from $O$. gomezii and $O$. morae from Costa Rica

\begin{tabular}{|c|c|c|c|c|c|c|c|}
\hline Compound $^{\mathrm{a}}$ & $\mathrm{RI}^{\mathrm{b}}$ & $O g \mathrm{~L}$ & $O g \mathrm{~B}$ & $O g \mathrm{~W}$ & $O m \mathrm{~L}$ & $O m \mathrm{~B}$ & $O m \mathrm{~W}$ \\
\hline pentan-2-ol & 689 & 12.5 & - & - & - & - & - \\
\hline pentanal & 706 & 0.1 & - & - & - & - & - \\
\hline hexanal & 803 & 0.1 & - & - & - & - & - \\
\hline heptan-2-one & 888 & - & - & - & 0.2 & $\mathrm{t}^{\mathrm{c}}$ & - \\
\hline heptan-2-ol & 894 & - & - & - & 0.1 & - & - \\
\hline heptanal & 900 & - & - & - & - & $\mathrm{t}$ & 0.6 \\
\hline santolina triene & 901 & 0.1 & - & - & - & - & - \\
\hline tricyclene & 927 & 0.1 & - & - & $\mathrm{t}$ & $\mathrm{t}$ & $\mathrm{t}$ \\
\hline$\alpha$-thujene & 930 & $\mathrm{t}$ & - & - & 0.2 & 0.1 & 0.1 \\
\hline$\alpha$-pinene & 937 & 1.1 & 0.1 & 0.1 & 10.4 & 2.9 & 3.5 \\
\hline$\alpha$-fenchene & 949 & - & - & - & - & - & $\mathrm{t}$ \\
\hline camphene & 951 & 0.1 & - & - & 0.6 & 2.1 & 3.8 \\
\hline thuja-2,4(10)-diene & 955 & 0.1 & - & - & - & $\mathrm{t}$ & - \\
\hline benzaldehyde & 961 & - & - & - & 0.1 & $\mathrm{t}$ & $\mathrm{t}$ \\
\hline sabinene & 975 & 0.1 & - & - & 0.1 & $\mathrm{t}$ & 0.5 \\
\hline$\beta$-pinene & 981 & 0.6 & 0.1 & 0.1 & 17.5 & 3.1 & 1.9 \\
\hline myrcene & 991 & - & - & - & 1.2 & 0.3 & 0.3 \\
\hline dehydro-1,8-cineole & 994 & 0.1 & - & - & - & $\mathrm{t}$ & $\mathrm{t}$ \\
\hline mesitylene & 995 & 0.1 & - & - & - & $\mathrm{t}$ & - \\
\hline$\alpha$-phellandrene & 1006 & $\mathrm{t}$ & - & - & 0.1 & $\mathrm{t}$ & - \\
\hline$\delta$-3-carene & 1013 & - & - & - & 0.1 & - & $\mathrm{t}$ \\
\hline$\alpha$-terpinene & 1019 & 0.1 & - & - & 0.1 & 0.1 & 0.1 \\
\hline p-cymene & 1025 & 1.8 & - & 0.3 & 0.2 & 0.1 & 0.2 \\
\hline$o$-cymene & 1026 & - & - & $\mathrm{t}$ & - & - & - \\
\hline limonene & 1030 & 0.1 & - & - & 0.8 & $\mathrm{t}$ & 0.4 \\
\hline 1,8-cineole & 1034 & 6.3 & 0.1 & 0.3 & 7.3 & 12.8 & 7.1 \\
\hline$(E)$ - $\beta$-ocimene & 1042 & - & - & - & 0.2 & - & - \\
\hline$(Z)$ - $\beta$-ocimene & 1049 & - & - & - & 0.4 & - & - \\
\hline$\gamma$-terpinene & 1060 & $\mathrm{t}$ & - & - & 0.2 & 0.2 & 0.2 \\
\hline cis-sabinene hydrate & 1069 & - & - & - & 0.3 & - & $\mathrm{t}$ \\
\hline terpinolene & 1089 & $\mathrm{t}$ & - & - & 0.1 & 0.1 & 0.1 \\
\hline nonan-2-one & 1093 & - & - & - & 0.7 & 0.3 & 0.1 \\
\hline linalool & 1097 & - & - & - & 0.5 & - & $\mathrm{t}$ \\
\hline
\end{tabular}

*e-mail: jfciccio@gmail.com 
Table S1. Percentage composition of the essential oils from O. gomezii and O. morae from Costa Rica (cont.)

\begin{tabular}{|c|c|c|c|c|c|c|c|}
\hline Compound $^{\mathrm{a}}$ & $\mathrm{RI}^{\mathrm{b}}$ & $O g \mathrm{~L}$ & $O g \mathrm{~B}$ & $O g \mathrm{~W}$ & $O m \mathrm{~L}$ & $O m \mathrm{~B}$ & $O m \mathrm{~W}$ \\
\hline nonan-2-ol & 1098 & - & - & - & - & 0.3 & 0.1 \\
\hline trans-sabinene hydrate & 1099 & - & - & - & $\mathrm{t}$ & - & - \\
\hline endo-fenchol & 1116 & - & - & - & - & $\mathrm{t}$ & - \\
\hline dehydro-sabina- ketone & 1117 & $\mathrm{t}$ & - & - & - & - & - \\
\hline$c i s$ - $p$-menth-2-en-1-ol & 1120 & - & - & - & - & $\mathrm{t}$ & - \\
\hline trans-pinocarveol & 1138 & 0.2 & - & - & 0.1 & 0.1 & - \\
\hline trans-p-menth-2-en-1-ol & 1140 & - & - & - & - & - & $\mathrm{t}$ \\
\hline sabinol $^{\mathrm{d}}$ & 1144 & 0.1 & - & - & - & - & - \\
\hline cis-pinene hydrate & 1145 & - & - & - & $\mathrm{t}$ & - & $\mathrm{t}$ \\
\hline camphor & 1147 & - & 0.1 & - & 0.2 & 3.1 & 3.4 \\
\hline camphene hydrate & 1150 & - & - & - & - & $\mathrm{t}$ & $\mathrm{t}$ \\
\hline isoborneol & 1157 & - & - & - & - & $\mathrm{t}$ & - \\
\hline pinocarvone & 1163 & $\mathrm{t}$ & - & - & - & $\mathrm{t}$ & - \\
\hline$\delta$-terpineol & 1166 & 0.1 & - & - & $\mathrm{t}$ & 0.7 & 0.2 \\
\hline borneol & 1167 & - & - & - & 0.2 & 0.3 & 0.2 \\
\hline pinocampheol & 1173 & - & - & - & - & $\mathrm{t}$ & - \\
\hline terpinen-4-ol & 1177 & 0.2 & - & - & 0.3 & 1.8 & 0.8 \\
\hline santalone & 1179 & - & 0.1 & - & - & - & - \\
\hline$p$-cymen-8-ol & 1185 & - & - & - & - & $\mathrm{t}$ & - \\
\hline cryptone & 1187 & 0.2 & - & - & - & - & - \\
\hline$\alpha$-terpineol & 1191 & 0.5 & 0.2 & - & 1.1 & 3.3 & 1.5 \\
\hline dihydro carveol & 1196 & 0.2 & - & - & - & - & - \\
\hline myrtenol & 1197 & - & - & - & $\mathrm{t}$ & 0.2 & - \\
\hline myrtenal & 1197 & $\mathrm{t}$ & - & - & 0.2 & $\mathrm{t}$ & - \\
\hline cis-piperitol & 1199 & - & - & - & - & $\mathrm{t}$ & - \\
\hline trans-carveol & 1220 & 0.1 & - & - & - & - & - \\
\hline cis-carveol & 1224 & $\mathrm{t}$ & - & - & - & - & - \\
\hline cumin aldehyde & 1237 & 0.1 & - & - & - & $\mathrm{t}$ & - \\
\hline carvone & 1244 & 0.1 & - & - & - & - & - \\
\hline piperitone & 1256 & - & - & - & - & $\mathrm{t}$ & - \\
\hline isobornyl acetate & 1286 & 0.1 & - & - & - & - & - \\
\hline bornyl acetate & 1287 & - & - & $\mathrm{t}$ & 0.1 & 0.1 & - \\
\hline undecan-2-one & 1289 & - & - & - & - & $\mathrm{t}$ & - \\
\hline 2-ethyl-isomenthone & 1294 & 0.1 & - & - & - & - & - \\
\hline$\delta$-elemene & 1338 & - & - & 0.1 & 0.3 & $\mathrm{t}$ & - \\
\hline$\alpha$-cubebene & 1351 & 0.3 & 3.9 & 0.5 & 0.5 & 2.4 & 3.4 \\
\hline$\alpha$-ylangene & 1372 & - & 1.9 & 0.1 & $\mathrm{t}$ & $\mathrm{t}$ & - \\
\hline isoledene & 1374 & 0.1 & - & - & - & - & - \\
\hline$\alpha$-copaene & 1378 & 1.2 & - & 0.9 & 2.9 & 3.3 & 4.9 \\
\hline$\beta$-bourbonene & 1381 & - & - & - & 0.2 & - & - \\
\hline dodecan-3-one & 1385 & - & - & - & - & - & $\mathrm{t}$ \\
\hline$\beta$-cubebene & 1387 & $\mathrm{t}$ & $\mathrm{t}$ & $\mathrm{t}$ & $\mathrm{t}$ & 1.0 & 5.2 \\
\hline$\beta$-elemene & 1391 & $\mathrm{t}$ & 1.5 & 1.1 & 2.3 & 0.8 & - \\
\hline 7-epi-sesquithujene & 1393 & - & - & - & - & - & $\mathrm{t}$ \\
\hline$\alpha$-gurjunene & 1406 & $\mathrm{t}$ & 0.1 & - & - & - & - \\
\hline cis- $\alpha$-bergamotene & 1412 & - & - & - & $\mathrm{t}$ & $\mathrm{t}$ & 0.1 \\
\hline$\alpha$-santalene & 1418 & - & 0.8 & 1.3 & - & - & - \\
\hline$\beta$-caryophyllene & 1418 & - & 2.0 & $\mathrm{t}$ & 7.1 & 6.1 & 5.4 \\
\hline$\beta$-ylangene & 1419 & 0.1 & - & - & - & - & - \\
\hline$\beta$-copaene & 1427 & 0.3 & $\mathrm{t}$ & $\mathrm{t}$ & 0.2 & - & $\mathrm{t}$ \\
\hline$\beta$-gurjunene & 1435 & 0.2 & - & - & - & - & - \\
\hline$\alpha$-guaiene & 1435 & - & - & & 0.1 & 0.1 & $\mathrm{t}$ \\
\hline trans- $\alpha$-bergamotene & 1436 & - & 1.9 & 0.6 & - & - & - \\
\hline
\end{tabular}


Table S1. Percentage composition of the essential oils from $O$. gomezii and $O$. morae from Costa Rica (cont.)

\begin{tabular}{|c|c|c|c|c|c|c|c|}
\hline Compound $^{\mathrm{a}}$ & $\mathrm{RI}^{\mathrm{b}}$ & $O g \mathrm{~L}$ & $O g \mathrm{~B}$ & $O g \mathrm{~W}$ & $O m \mathrm{~L}$ & $O m \mathrm{~B}$ & $O m \mathrm{~W}$ \\
\hline aromadendrene & 1437 & - & - & - & 0.3 & - & - \\
\hline$(Z)-\beta$-farnesene & 1442 & - & - & - & $\mathrm{t}$ & $\mathrm{t}$ & 0.1 \\
\hline cis-muurola-3,5-diene & 1449 & 1.7 & 0.6 & 0.7 & - & - & 2.0 \\
\hline trans-muurola-3,5-diene & 1452 & $\mathrm{t}$ & - & - & - & $\mathrm{t}$ & $\mathrm{t}$ \\
\hline$\alpha$-humulene & 1452 & $\mathrm{t}$ & 0.7 & $\mathrm{t}$ & 2.8 & 2.0 & 0.7 \\
\hline allo-aromadendrene & 1458 & 2.1 & 5.7 & 0.4 & 0.5 & 0.4 & 0.1 \\
\hline cis-muurola-4(14),5-diene & 1463 & 4.1 & 1.4 & 0.7 & - & - & - \\
\hline cis-thujopsadiene & 1468 & 1.2 & - & - & - & - & - \\
\hline trans-cadina-1(6),4-diene & 1474 & - & - & - & - & 0.6 & 0.4 \\
\hline$\gamma$-gurjunene & 1473 & - & 0.5 & 0.3 & - & - & - \\
\hline$\gamma$-muurolene & 1476 & 0.9 & 1.3 & 0.7 & - & 0.4 & - \\
\hline$\alpha$-amorphene & 1478 & - & - & - & - & - & 1.4 \\
\hline germacrene D & 1480 & 0.2 & 0.1 & 0.1 & 7.5 & 0.1 & 2.9 \\
\hline$\beta$-selinene & 1485 & 0.1 & 1.5 & 0.7 & 5.5 & 5.4 & 0.5 \\
\hline$\delta$-selinene & 1489 & 1.6 & - & - & - & - & 2.2 \\
\hline cis- $\beta$-guaiene & 1494 & - & - & - & - & - & 0.6 \\
\hline trans-muurola-4(14),5-diene & 1488 & - & 0.1 & - & - & - & - \\
\hline$\gamma$-amorphene & 1490 & 0.7 & - & 0.1 & - & - & - \\
\hline viridiflorene & 1497 & - & $\mathrm{t}$ & 0.2 & - & - & - \\
\hline bicyclogermacrene & 1497 & - & - & - & 8.8 & - & - \\
\hline epizonarene & 1499 & $\mathrm{t}$ & 0.6 & 4.1 & - & - & - \\
\hline$\alpha$-muurolene & 1500 & 4.0 & 6.9 & $\mathrm{t}$ & - & 1.8 & - \\
\hline$\alpha$-bulnesene & 1500 & - & - & - & 1.3 & 0.5 & - \\
\hline$\delta$-amorphene & 1506 & - & - & - & - & 0.5 & - \\
\hline$\gamma$-cadinene & 1514 & 5.1 & 5.9 & 3.2 & 1.0 & 0.5 & 1.8 \\
\hline cubebol & 1516 & - & - & $\mathrm{t}$ & $\mathrm{t}$ & 0.5 & 0.6 \\
\hline$\delta$-cadinene & 1525 & 7.7 & 14.5 & 7.7 & 2.9 & 5.5 & 6.2 \\
\hline trans-calamenene & 1527 & - & - & 3.3 & - & - & - \\
\hline zonarene & 1530 & - & - & - & - & - & 0.2 \\
\hline cis-calamenene & 1532 & - & - & - & - & $\mathrm{t}$ & - \\
\hline trans-cadina-1,4-diene & 1533 & 1.3 & 0.1 & 0.6 & 0.2 & 0.3 & 0.7 \\
\hline 10-epi-cubebol & 1535 & 0.1 & - & - & - & - & - \\
\hline$\alpha$-cadinene & 1538 & - & 0.4 & 0.1 & 0.2 & $\mathrm{t}$ & 0.2 \\
\hline$\alpha$-calacorene & 1544 & 2.5 & 2.7 & 3.3 & 0.1 & 0.6 & $\mathrm{t}$ \\
\hline italicene epoxide & 1548 & 0.8 & - & - & - & - & - \\
\hline elemol & 1551 & - & 1.8 & 1.9 & 0.7 & 0.4 & 0.2 \\
\hline germacrene B & 1556 & - & 0.3 & 0.6 & - & - & - \\
\hline (E)-nerolidol & 1562 & - & - & - & - & $\mathrm{t}$ & 11.4 \\
\hline$\beta$-calacorene & 1564 & 0.4 & 0.5 & 0.7 & 0.1 & - & $\mathrm{t}$ \\
\hline palustrol & 1568 & - & - & - & - & 0.3 & - \\
\hline germacrene-D-4-ol & 1573 & - & - & - & 0.1 & - & - \\
\hline spathulenol & 1577 & - & 0.2 & 1,2 & 2.2 & 3.7 & 0.6 \\
\hline caryophyllene oxide & 1581 & - & - & 1.0 & 1.5 & 5.5 & 1.9 \\
\hline globulol & 1584 & 3.8 & 4.2 & 3.5 & 0.2 & - & $\mathrm{t}$ \\
\hline gleenol & 1588 & $\mathrm{t}$ & 0.3 & $\mathrm{~T}$ & - & - & - \\
\hline viridiflorol & 1593 & 4.9 & 3.6 & 4.0 & 0.1 & 0.2 & $\mathrm{t}$ \\
\hline salvial-4(14)-en-1-one & 1592 & - & - & - & - & $\mathrm{t}$ & $\mathrm{t}$ \\
\hline guaiol & 1598 & - & 3.3 & $\mathrm{t}$ & - & - & - \\
\hline$\beta$-atlantol & 1604 & - & - & - & - & 0.6 & - \\
\hline humulene epoxide II & 1607 & 1.1 & 0.7 & 1.0 & 0.3 & 1.4 & 0.2 \\
\hline 1,10-di-epi-cubenol & 1616 & 4.9 & 7.7 & 4.6 & - & - & - \\
\hline 1-epi-cubenol & 1628 & 0.6 & 1,8 & 0.4 & 0.6 & 4.0 & 2.2 \\
\hline cis-cadin-4-en-7-ol & 1635 & - & - & - & - & 0.7 & - \\
\hline
\end{tabular}


Table S1. Percentage composition of the essential oils from $O$. gomezii and $O$. morae from Costa Rica (cont.)

\begin{tabular}{|c|c|c|c|c|c|c|c|}
\hline Compound $^{\mathrm{a}}$ & $\mathrm{RI}^{\mathrm{b}}$ & $O g \mathrm{~L}$ & $O g \mathrm{~B}$ & $O g \mathrm{~W}$ & $O m \mathrm{~L}$ & $O m \mathrm{~B}$ & $O m \mathrm{~W}$ \\
\hline caryophylla-4(12),8(13)-dien-5 $\beta$-ol & 1641 & - & - & - & - & 1.6 & - \\
\hline epi- $\alpha$-cadinol & 1641 & 9.8 & 4.9 & 10.0 & 0.5 & 3.4 & 0.5 \\
\hline epi- $\alpha$-muurolol & 1642 & $\mathrm{t}$ & 2.0 & 15.0 & - & 1.8 & 6.3 \\
\hline$\alpha$-muurolol & 1649 & 0.3 & $\mathrm{t}$ & 0.3 & - & 1.2 & 1.3 \\
\hline cubenol & 1648 & - & - & - & 0.2 & - & $\mathrm{t}$ \\
\hline$\beta$-eudesmol & 1655 & - & - & $\mathrm{t}$ & - & - & - \\
\hline$\alpha$-cadinol & 1655 & 0.7 & 5.3 & 2.3 & 1.1 & 5.3 & 6.0 \\
\hline selin-11-en-4-ol & 1661 & - & - & - & - & 0.4 & $\mathrm{t}$ \\
\hline cis-calamenen-10-ol & 1662 & 0.5 & - & 0.6 & 0.1 & - & 0.1 \\
\hline trans-calamenen-10-ol & 1667 & 0.3 & - & 0.5 & 0.4 & $\mathrm{t}$ & - \\
\hline 14-hydroxy-9-epi-(E)-caryophyllene & 1672 & - & - & - & 0.1 & 1.2 & - \\
\hline bulnesol & 1673 & - & 1.4 & - & - & - & - \\
\hline (Z)- $\alpha$-santalol & 1677 & - & - & - & - & - & 0.1 \\
\hline cadalene & 1676 & 0.4 & 0.6 & 1.0 & 0.5 & $\mathrm{t}$ & - \\
\hline khusinol & 1682 & - & 1.2 & 4.6 & 0.4 & 0.4 & - \\
\hline eudesma-4(15),7-dien-1 $\beta$-ol & 1686 & 0.9 & - & - & - & 0.8 & 0.3 \\
\hline cis-14-nor-muurol-5-en-4-one & 1689 & 0.8 & - & - & - & - & - \\
\hline heptadecane & 1700 & - & - & - & - & - & 0.2 \\
\hline 10-nor-calamenen-10-one & 1707 & 0.2 & - & 0.5 & 0.1 & 0.1 & 0.3 \\
\hline mint sulfide & 1738 & - & - & - & - & - & 0.1 \\
\hline benzyl benzoate & 1761 & - & - & - & 0.4 & - & - \\
\hline cyclocolorenone & 1761 & 0.3 & - & - & - & - & - \\
\hline aristolone & 1763 & 1.0 & - & - & - & - & - \\
\hline 14-hydroxy- $\alpha$-muurolene & 1772 & 0.1 & $\mathrm{t}$ & - & 0.1 & - & - \\
\hline 14 -hydroxy- $\delta$-cadinene & 1810 & - & - & 1.1 & - & - & - \\
\hline benzyl salicylate & 1861 & - & - & - & 0.1 & - & - \\
\hline hexadecanoic acid & 1964 & - & - & 3.0 & - & - & - \\
\hline Total oil composition (\%) & & 92.7 & 95.6 & 89.4 & 98.1 & 97.8 & 96.4 \\
\hline Monoterpene hydrocarbons & & 4.2 & 0.2 & 0.5 & 32.2 & 9.0 & 11.1 \\
\hline Oxygenated monoterpenes & & 8.4 & 0.5 & 0.3 & 10.3 & 22.4 & 13.2 \\
\hline Sesquiterpene hydrocarbons & & 36.2 & 56.5 & 33.1 & 45.3 & 32.3 & 39.0 \\
\hline Oxygenated sesquiterpenes & & 31.1 & 38.4 & 52.5 & 8.7 & 33.5 & 32.0 \\
\hline Others & & 12.8 & - & 3.0 & 1.6 & 0.6 & 1.1 \\
\hline
\end{tabular}

${ }^{\mathrm{a}}$ Compounds listed in order of elution from 5\% phenyl-95\% methylpolysiloxane column; ${ }^{\mathrm{b} I}=$ Retention index relative to a homologous series of $n$-alkanes on the 5\% phenyl-95\% methylpolysiloxane column; ${ }^{\mathrm{c}} \mathrm{t}=$ traces $(<0.05 \%)$; ${ }^{\mathrm{d} C o r r e c t}$ isomer not identified. OgL: Ocotea gomezii (leaves), OgB: $O$. gomezii (bark), $O g \mathrm{~W}$ : O. gomezii (wood), OmL: O. morae (leaves), OmB: O. morae (bark), OmW: O. morae (wood). 